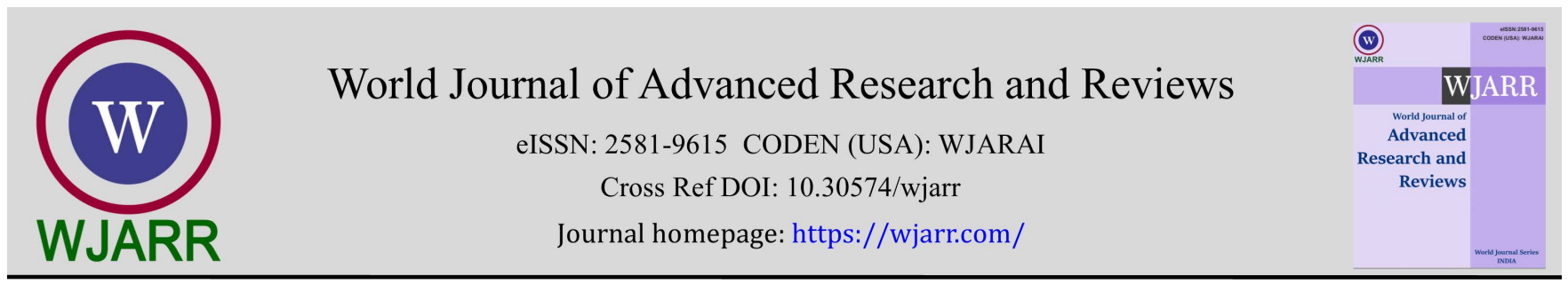

(RESEARCH ARTICLE)

\title{
Implications of dietary Delonix regia seed meal on growth, feed utilization, haematology and fillet yield of red Nile tilapia Oreochromis niloticus
}

\author{
Saviour Isonguyoh Umanah and Gift Samuel David* \\ Department of Fisheries and Aquatic Environmental Management, Faculty of Agriculture, University of Uyo, Uyo, Akwa \\ Ibom State, Nigeria.
}

World Journal of Advanced Research and Reviews, 2021, 12(01), 140-154

Publication history: Received on 02 September 2021; revised on 07 October 2021; accepted on 09 October 2021

Article DOI: https://doi.org/10.30574/wjarr.2021.12.1.0508

\begin{abstract}
Delonix regia is commonly called Flamboyant or flame of the forest. The seeds were fermented, boiled, sundried and then ground into powdered meal. 40\% crude protein based test diets containing Delonix regia seed meal D0 = $0 \%$; D15 = 15\%; D20 = 20\% and D25 = 25\% inclusion levels respectively were prepared. Red tilapia (Oreochromis niloticus) fingerlings of 6 weeks old were acclimatized for two weeks and then stocked in 12 hapas at 15 fish per hapa measuring $0.6 \mathrm{~m} \times 1.2 \mathrm{~m} \times 0.7 \mathrm{~m}$ placed in a concrete tank. Each diet was assigned to fish in a separate hapa in triplicate and administered at $3 \%$ fish body weight per day for 16 weeks. Fish weight and length were taken initially, bi-weekly and terminally. Water quality was monitored weekly. Number of fish at the end was recorded and survival rate, growth, feed utilization, fillet yield and blood parameters were determined. The data were subjected to the analysis of variance and mean separation $(P=0.05)$. Survival rate was highest in fish raised on D20 and least in D25 without any significant difference across the range. Mean growth performances, feed utilization indices and fillet yield were generally congruent between D20 and D25 with varying degrees of significant difference to other feeds. Results of blood assay did not depict harmful effects of the test diets indicating that the fish enjoyed some good measures of health. The gross performance of fish on D20 was optimal. It was therefore concluded that $20 \%$ dietary inclusion level of fermented, cooked and dried flamboyant seed was the best for the red tilapia (Oreochromis niloticus) post fingerlings.
\end{abstract}

Keywords: Delonix regia; Red tilapia (Oreochromis niloticus); Growth performance; Feed utilization; Haematological (blood) indices; Fillet yield

\section{Introduction}

Adequate fish nutrition is a fundamental requirement for a successful aquacultural enterprise especially as feed provides the nutritional basis for fish growth and constitutes the largest operational cost [1 - 3]. The high cost of feeds is a serious constraint [4] to aquaculture production and is consequent on the scarcity of fish feed stuffs and the attendant exorbitant cost [5] for local feed production in the developing countries. In order to address this concern, many authors [6 - 14] have considered the possibility of locally available and cheap alternative feed ingredients particularly, low economic plants sources without compromising feed quality.

Flamboyant (Delonix regia) seeds and bye products are possible materials which potentials as feed stuff for both livestock and aqua feeds are being considered $[15,16]$. Flamboyant (D. regia) is a wild plant otherwise called flame of the forest. It is an ornamental, leguminous plant, which produces large quantities of seeded pods in the fruiting season [15]. The seeds are rich in many important nutrients (protein, amino acid, vitamins, minerals, oils and carbohydrates). According to Alemede et al. [17] and Bake et al. [18], the seeds contains $18.16-29.58 \%$ crude protein and $7.0-9.39 \%$

\footnotetext{
${ }^{*}$ Corresponding author: Gift Samuel David

Department of Fisheries and Aquatic Environmental Management, Faculty of Agriculture, University of Uyo, Uyo, Akwa Ibom State, Nigeria.
}

Copyright $(2021$ Author(s) retain the copyright of this article. This article is published under the terms of the Creative Commons Attribution Liscense 4.0. 
crude lipids. Grant et al. [19] had even reported crude protein content of 36. \%. The utilization of D. regia seeds, as with many other feedstuffs of plant origin, could be limited on account of the presence of anti-nutritional factors capable of inducing serious physiological and pathological consequences. Plant anti-nutrient include alkaloids, cyanogenic glycosides, oxalic acid, phytates, phytic acid, lectins, goitrogens, amylase inhibitors, protease inhibitors, haemagglutinin, saponin, mimosine, gossypol and anti-vitamins [20 - 22]. However, with proper processing techniques (such as soaking, fermentation, toasting, boiling and germination), these bioactive compounds of plant could be destroyed or drastically reduced $[23,24]$ to enable the use of certain plant feedstuffs for aqua feed manufacture.

Red tilapia (Oreochromis niloticus) is a hybrid from the cross between a mutant orange coloured 0 . mossambicus and 0 . niloticus [25,26]. Other hybrids of the same mutant 0 . mossambicus and 0 . aureus or 0 . hornorum are also red [26 - 30]. Generally, red tilapia has an appealing colour similar to the marine fishes, sea bream (Chrysophrys major) and red snapper (Lutjanus campechanus) [31] which makes it attractive to the people both as food and aquarium fish thus commanding higher demand and prices [32,33]. However, it is still a novel tilapia strain in the Nigeria's aquaculture system and announces a striking appearance where ever it is found thus presenting a potential huge market. Optimization of the production efficiency in the culture of this fish through the development of cheaper feed is necessary especially, as the cost of feed is highly affected by the cost of feed ingredients. The aim of this work is to evaluate the suitability of $D$. regia seed meal as a feed ingredient in the diets of red tilapia $(O$. niloticus) with respect to growth performance, health and fillet yield.

\section{Materials and methods}

\subsection{Research location}

The fish farm complex of Safe Food MPCS Ltd along Phenson Street, Federal Housing Estate, Abak Road, Uyo, Nigeria was used for the research.

\subsection{Experimental fish}

Three hundred (300) fingerlings of six-weeks old red tilapia Oreochromis niloticus were harvested from the production tank in Safe Foods MPCS and kept in two large hapas $(1.5 \mathrm{~m}$ by $2.0 \mathrm{~m}$ by $0.7 \mathrm{~m})$ placed in a $2 \mathrm{~m} \times 4$ m concrete tank for two weeks of acclimation before commencement of the experiment. During the acclimation period, the fish were fed with commercial feed (Coppens) at 3\% total body weight (bwt) per day given in two rations. Water parameters were monitored weekly.

\subsection{Seed collection and processing}

Delonix regia seeds were threshed from dry pods collected from parent trees beside Abak and Nwaniba roads, in Uyo, Akwa Ibom State, where they were massively planted for ornamental purposes. The viable seeds of $D$. regia were soaked for 24 hours in water to initiate fermentation, cooked for 90 minutes at $80^{\circ} \mathrm{C}$, washed and sun dried for 72 hours, all in order to deactivate growth inhibitors [18]. The dried seeds were ground into fine powder. The proximate composition, total oxalate, tannin and HCN content of the raw and cooked seeds were determined [34] while phytate was analyzed by modified method of [35].

\subsection{Formulation and preparation of experimental diets}

Forty percent (40\%) crude protein based diets were formulated according to the composition in Table 1, prepared, the pellets sundried to constant weight and packaged in distinct labelled polythelene bags according to feed type for storage till needed. The formulation of each of the 4 diets recognized the crude protein content of the processed $D$. regia seeds. The diet D0 = 0\% Delonix regia seed meal (DSM) was the control. Proximate analysis of each feed samples was conducted [34]. 
Table 1 Formulation of the Experimental Diets and Proximate Composition

\begin{tabular}{|l|c|c|c|c|}
\hline \multirow{2}{*}{ Ingredients } & \multicolumn{4}{c|}{ Percentage Composition } \\
\cline { 2 - 5 } & D0 & D15 & D20 & D25 \\
\hline Fish meal & 25 & 25 & 25 & 25 \\
\hline Flamboyant seed meal & 0 & 15 & 20 & 25 \\
\hline Soybean meal & 13.635 & 13.635 & 13.635 & 13.635 \\
\hline Groundnut cake & 20 & 20 & 20 & 20 \\
\hline Blood meal & 10 & 10 & 10 & 10 \\
\hline Lysine & 1 & 1 & 1 & 1 \\
\hline Methionine & 0.5 & 0.5 & 0.5 & 0.5 \\
\hline Vitamin premix & 0.25 & 0.25 & 0.25 & 0.25 \\
\hline Vitamin C & 0.015 & 0.015 & 0.015 & 0.015 \\
\hline Bone ash & 2.1 & 2.1 & 2.1 & 2.1 \\
\hline Palm oil & 0.5 & 0.5 & 0.5 & 0.5 \\
\hline Composite wheat flour & 1.5 & 1.5 & 1.5 & 1.5 \\
\hline Wheat offal & 25 & 10 & 5 & 0 \\
\hline Salt & 0.5 & 0.5 & 0.5 & 0.5 \\
\hline Total percentage & 100 & 100 & 100 & 100 \\
\hline \% wheat offal replacement & 0 & 60 & 80 & 100 \\
\hline
\end{tabular}

\subsection{Experimental protocol}

Twelve hapas with dimensions of $1.2 \mathrm{~m}$ x $0.6 \mathrm{~m}$ x $0.6 \mathrm{~m}$ were constructed and set in a $2 \mathrm{~m} \times 8 \mathrm{~m}$ concrete tank. Fifteen (15) Oreochromis niloticus juveniles were stocked in each hapa. Three random hapas were assigned to each separate feed type giving four treatments and three replicates. Feeding of fish in each replicate was done twice daily at 8 - 8:30 am and $6-6: 30 \mathrm{pm}$ at $1.5 \%$ fish bwt each time and the daily quantity of feed adjusted to $3 \%$ fish bwt following every weight measurement during the experiment. Weights of fish were taken at the commencement, fortnightly during, and at the end of the experiment in 16 weeks. Water quality was ensured through weekly total exchange with fresh water and daily monitoring of certain quality parameters before each feeding. The observed mean ranges of water quality indices (dissolved oxygen: $6.36 \pm 0.36-7.18 \pm 0.18$; temperature: $27.11 \pm 0.60-28.54 \pm 0.54 ; \mathrm{pH}: 6.83 \pm 0.41-7.14 \pm$ 0.41 ) were considerable for tilapia under warm water aquaculture [36 - 38]. Proximate composition of the experimental fish was analyzed pre and post feeding trial. At the end of the experiment, the fish in each hapa were audited and equal number of fish taken from each hapa across the entire size range for haematological assay and fillet yield determination.

\subsection{Determination of haematological parameters}

Blood was collected from each of 4 fish (weight: $50.81-68.00 \mathrm{~g}$; length: $17.88-19.40 \mathrm{~cm}$ ) sampled from each replicate into separate heparinized bottles by ventral aorta severance. The erythrocytes (RBC) and white blood cells (WBC) counts were obtained using improved Neubauer haemocytometer with standard diluents, and calculated according to Blaxhall and Daisley [39]. The micro-haematocrit method was used for the determination of percentage haematocrit and determination of haemoglobin conducted using haemoglobinometer (Coulter, UK). Standard methods [39, 40] were employed in the estimation of the erythrocytic parameters: Mean cell haemoglobin $(\mathrm{MCH}, \mathrm{pg})=(\mathrm{Hb} \times 10)(\mathrm{RBC})^{-1}$; Mean corpuscular volume $(\mathrm{MCV}, \mathrm{fl})=(\mathrm{Hct} \times 10)(\mathrm{RBC})^{-1}$; and Mean cell haemoglobin concentration $(\mathrm{MCHC}, \mathrm{g} / \mathrm{dl})=(\mathrm{Hb} \times 100)$ $(\mathrm{PCV})^{-1}$ 


\subsection{Determination of percentage fillet weight}

Six fish samples (weight: $50.89-68.00 \mathrm{~g}$; length: $17.94-19.44 \mathrm{~cm}$ ) were taken out from each replicate of a treatment for weight and length determination. All the discarded parts of the fish which include scales, fin, viscera, heads and bones were separated from the fish manually leaving only the flesh (fillet) which weight was measured. Percentages of these various parameters were calculated and the fillet yield was estimated as follows.

$$
\text { Fillet Yield }(\%)=\frac{\text { flesh weight }}{\text { fish total weight }} \times 100
$$

\subsection{Growth performance and feed utilization parameters}

Growth performance, survival rate and feed utilization were processed as follows.

Mean Weight Gain (MWG)

$$
M W G=W_{1}-W_{0}
$$

Where $\mathrm{W}_{0}=$ Initial mean weight and $\mathrm{W}_{1}=$ Final mean weight

Specific Growth Rate (SGR) [41]

$$
S G R=\frac{100 \times\left(\operatorname{In} W_{2}-\operatorname{In} W_{1}\right)}{t}
$$

Where In $\mathrm{W}_{2}=$ Natural Logarithm of final weight; In $\mathrm{W}_{1}=$ Natural Logarithm of initial weight and $t=$ Total number of days less day one

Survival Rate (SR)

$$
S R=\frac{\text { Final number of fish }}{\text { Initial number of fish }} \times 100
$$

Protein Index (PI)

$$
P I=\frac{\text { protein consumed }}{100}
$$

Protein efficiency ratio (PER) [42]

$$
\text { PER }=\frac{\text { Weight gain }(g)}{\text { Protein intake }(g)}
$$

Where, protein intake

$$
\text { Protein intake }=\frac{\% \text { protein in feed } \times \text { total diet consumed }}{100}
$$

Feed conversion ratio (FCR) [43]

$$
F C R=\frac{\text { Dry weight feed consumed }(g)}{\text { Weight gain }(g)}
$$

\subsection{Statistical analysis}

The growth performance, feed utilization, fillet yield, proximate composition and haematological indices results obtained were subjected to one-way Analysis of Variance (ANOVA) for significant differences at 0.05 level of probability and the treatment means separated with Duncan Multiple Range test. Statistical Package for Social Sciences (SPSS) Version 25 was used for the analysis. 


\section{Results}

The nutritional compositions of the formulated feeds and Delonix regia seeds with the anti- nutrients content are shown in the following Table 2. The results of the analysis have shown the positive effect of the processing methods adopted on the D. regia seeds. The anti -nutrients levels have been reduced as well as ash whereas the levels of protein and lipids got elevated though, slight reduction occurred in the levels of crude NFE and energy. The 4 feeds prepared were observed to possess similar crude protein levels with minimal increments as the D. regia seed meal increased from D0 - D25. However, increment of lipid value as DSM increased was very obvious. The growth performance exhibited by the red tilapia in response to the experimental treatments are presented in Tables 3.

Table 2 Proximate composition of the formulated diets and Delonix regia seed including the anti-nutritional factors

\begin{tabular}{|c|c|c|c|c|c|c|c|}
\hline \multirow[t]{2}{*}{ Proximate composition (\%) } & \multicolumn{4}{|c|}{ Treatments } & \multicolumn{2}{|c|}{ Delonix regia seed } & \\
\hline & D0 & D15 & D20 & D25 & Raw & Cooked & \\
\hline Moisture & 7.15 & 7.31 & 7.26 & 7.08 & 11.65 & 8.67 & \\
\hline Ash & 10.25 & 9.50 & 9.42 & 9.19 & 4.06 & 1.41 & \\
\hline Fiber & 13.94 & 9.50 & 9.73 & 8.49 & 10.58 & 11.06 & \\
\hline Protein & 40.25 & 40.35 & 40.46 & 40.80 & 11.90 & 16.8 & \\
\hline Lipid & 4.20 & 6.15 & 7.36 & 9.10 & 6.85 & 7.18 & \\
\hline NFE & 31.36 & 34.50 & 33.03 & 32.42 & 66.61 & 63.55 & \\
\hline Calories (kcal/100g) & 368.50 & 369.54 & 370.60 & 371.20 & 394.31 & 389.47 & \\
\hline \multirow{2}{*}{$\begin{array}{l}\text { Anti-nutrients } \\
\text { (mg/100g) }\end{array}$} & \multirow[t]{2}{*}{ Cooked } & \multirow[t]{2}{*}{ Raw } & \multirow[t]{2}{*}{ Reduction (\%) } & \multicolumn{4}{|c|}{ Exported to feed $(\mathrm{mg} / \mathrm{kg})$} \\
\hline & & & & D0 & D15 & D20 & D25 \\
\hline HCN & 12.87 & 1.61 & 87.49 & 0.00 & 2.40 & 3.20 & 4.00 \\
\hline Tannin & 98.93 & 20.94 & 78.83 & 0.00 & 31.40 & 41.88 & 52.35 \\
\hline Phytate & 45.06 & 6.52 & 85.53 & 0.00 & 9.78 & 13.40 & 16.30 \\
\hline Total oxalate & 243.45 & 76.00 & 68.78 & 0.00 & 114.00 & 152.00 & 190.00 \\
\hline
\end{tabular}

Table 3 Mean Growth Response of Red Tilapia (Oreochromis niloticus) to different levels of Dietary Delonix regia Seed Meal in Hapas over 16 Weeks

\begin{tabular}{|l|c|c|c|c|}
\hline \multirow{2}{*}{ Parameters } & \multicolumn{4}{c|}{ Treatments } \\
\cline { 2 - 5 } & D0 & D15 & D20 & D25 \\
\hline Mean final Weight (g) & $51.12 \pm 2.85^{\mathrm{a}}$ & $51.98 \pm 2.13^{\mathrm{a}}$ & $69.04 \pm 3.40^{\mathrm{b}}$ & $62.91 \pm 3.81^{\mathrm{b}}$ \\
\hline Mean initial Weigh(g) & $12.58 \pm 0.76^{\mathrm{a}}$ & $12.17 \pm 0.71^{\mathrm{a}}$ & $13.44 \pm 0.65^{\mathrm{a}}$ & $11.32 \pm 0.81^{\mathrm{a}}$ \\
\hline Mean weight gain (g) & $38.540 \pm 2.22^{\mathrm{b}}$ & $39.813 \pm 2.01^{\mathrm{b}}$ & $55.60 \pm 2.76^{\mathrm{a}}$ & $51.59 \pm 4.59^{\mathrm{a}}$ \\
\hline Mean final length (cm) & $17.95 \pm 0.94^{\mathrm{a}}$ & $17.65 \pm 0.30^{\mathrm{a}}$ & $19.43 \pm 0.31^{\mathrm{a}}$ & $17.89 \pm 0.58^{\mathrm{a}}$ \\
\hline Mean initial length (cm) & $13.63 \pm 0.42^{\mathrm{a}}$ & $13.67 \pm 0.25^{\mathrm{a}}$ & $14.02 \pm 0.25^{\mathrm{a}}$ & $13.17 \pm 0.36^{\mathrm{a}}$ \\
\hline Mean growth rate (\%) & $1.081 \pm 0.02^{\mathrm{c}}$ & $1.11 \pm 0.03^{\mathrm{bc}}$ & $1.2 \pm 0.04^{\text {ab }}$ & $1.24 \pm 0.06^{\mathrm{a}}$ \\
\hline Specific growth rate (\%) & $1.26 \pm 0.03^{\mathrm{b}}$ & $1.31 \pm 0.05^{\mathrm{b}}$ & $1.47 \pm 0.01^{\mathrm{b}}$ & $1.55 \pm 0.11^{\mathrm{a}}$ \\
\hline Condition factor & $0.89 \pm 0.01^{\mathrm{a}}$ & $0.95 \pm 0.3^{\mathrm{a}}$ & $0.94 \pm 0.03^{\mathrm{a}}$ & $1.13 \pm 1.19^{\mathrm{a}}$ \\
\hline Survival rate & $97.78 \pm 2.22^{\mathrm{a}}$ & $99.11 \pm 4.45^{\mathrm{a}}$ & $100.00^{\mathrm{a}}$ & $95.55 \pm 4.45^{\mathrm{a}}$ \\
\hline \multicolumn{4}{|c|}{ Means in the same row with similar super scripts are not significantly different $(\mathrm{P}>0.05)}$.
\end{tabular}


The survival of the red tilapia (Oreochromis niloticus) was highest in fish fed diet D20 and slightly lower in D25, though there was no significant difference among all the treatments $(P>0.05)$. The highest mean weight gain (MWG) recorded in treatment D20 was not significantly different from the closest value in treatment D25 $(P>0.05)$ and both values differed significantly from treatments D0 and D15 $(P<0.05)$ which were similar $(P>0.05)$. The values of Mean Growth Rate (MGR) and Specific Growth Rate (SGR) declined progressively from their respective highest in D25 to their lowest in D0. For MGR, treatments D20 and D25; D15 and D20 as well as D0 and D15 were respectively not significantly different $(P>0.05)$, while treatments D0, D15 and D20 in SGR were also not significantly different $(P>0.05)$. The index of robustness, condition factor $(\mathrm{K})$ progressively increased from the minimum score in treatment D0 to its peak in treatment D25, but without significant differences among the various treatments $(P>0.05)$. The growth pattern of the red tilapia Oreochromis niloticus on bi-weekly cumulative basis shown in Table 4 and Figure 1 depicted higher growth in the first six weeks of stocking compared to the following weeks of the experiment.

Table 4 Mean bi-weekly weight gain and cumulative weight gain of red tilapia Oreochromis niloticus in response to dietary Delonix regia seed meal over 16 weeks

\begin{tabular}{|l|c|c|c|c|c|c|c|c|}
\hline \multirow{2}{*}{$\begin{array}{c}\text { Time } \\
\text { (weeks) }\end{array}$} & \multicolumn{4}{|c|}{ Weight gain (g) } & \multicolumn{4}{c|}{ Cumulative weight gain (g) } \\
\cline { 2 - 9 } & D0 & D15 & D20 & D25 & D0 & D15 & D20 & D25 \\
\hline 0 & 0 & 0 & 0 & 0 & 0 & 0 & 0 & 0 \\
\hline 2 & 6.39 & 5.33 & 2.62 & 1.07 & 8.14 & 5.33 & 2.64 & 1.07 \\
\hline 4 & 12.72 & 11.63 & 10.85 & 8.54 & 19.12 & 16.95 & 13.47 & 9.61 \\
\hline 6 & 2.02 & 1.57 & 8.26 & 8.28 & 21.14 & 18.52 & 21.73 & 17.89 \\
\hline 8 & 4.54 & 5.12 & 6.24 & 9.29 & 25.67 & 23.64 & 27.97 & 27.19 \\
\hline 10 & 2.29 & 2.46 & 3.64 & 4.53 & 27.29 & 26.11 & 31.61 & 95.16 \\
\hline 12 & 4.14 & 3.27 & 6.71 & 7.12 & 31.43 & 29.37 & 38.33 & 38.84 \\
\hline 14 & 3.03 & 6.1 & 11.64 & 8.28 & 34.46 & 5.47 & 49.97 & 47.11 \\
\hline 16 & 4.08 & 4.34 & 5.63 & 4.48 & 38.54 & 39.81 & 55.6 & 51.59 \\
\hline
\end{tabular}

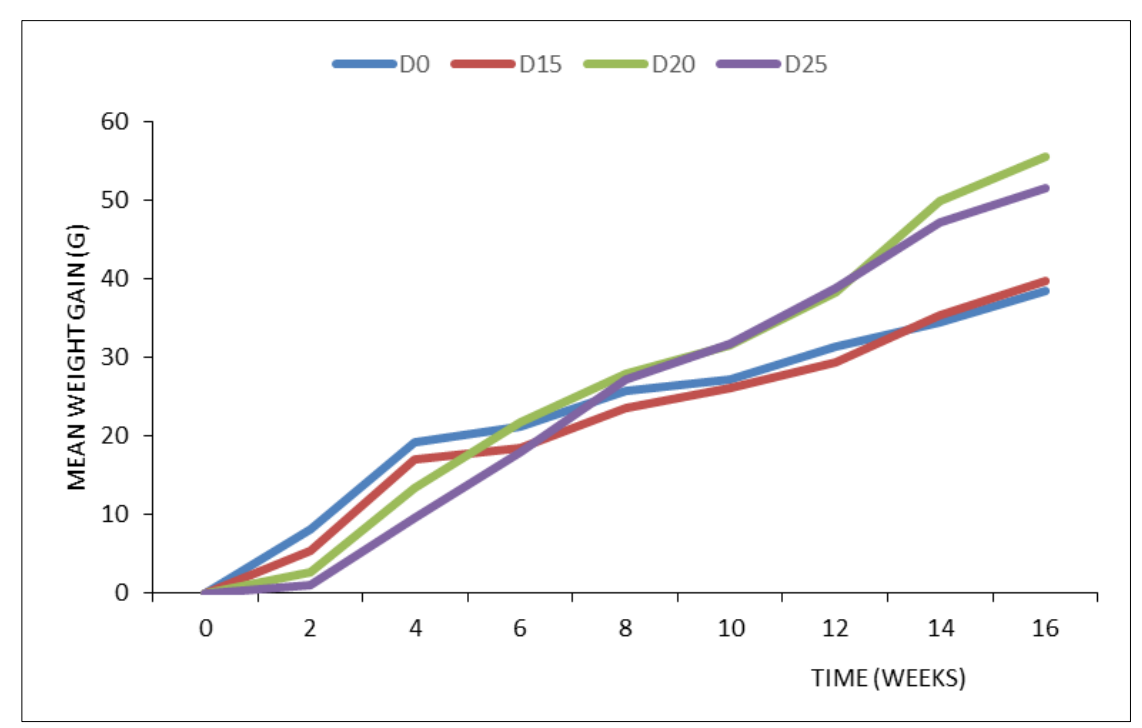

Figure 1 Mean bi-weekly cumulative weight gain of red tilapia in response to different dietary levels of Delonix regia seed meal over 14 weeks

Mean feed utilization indices of the red tilapia obtained are shown in Table 5. The highest amount of feed and crude protein consumed, and PI were observed in fish raised on feed D20 but these did not differ significantly from the results 
of other feeds $(P>0.05)$. FCR, and PER got from D20 and D25 were similar but significantly better than in D0 and D15 which incidentally were insignificant different.

Table 5 Mean Feed Utilization of $O$. niloticus in response to different dietary levels of $D$. regia seed meal over 16 weeks

\begin{tabular}{|l|c|c|c|c|}
\hline \multirow{2}{*}{ Parameters } & \multicolumn{4}{c|}{ Treatments } \\
\cline { 2 - 5 } & D0 & D15 & D20 & D25 \\
\hline Feed consumed (g) & $70.35 \pm 3.41^{\mathrm{a}}$ & $69.67 \pm 21.56^{\mathrm{a}}$ & $80.16 \pm 5.34^{\mathrm{a}}$ & $71.71 \pm 2.02^{\mathrm{a}}$ \\
\hline Protein consumed (g) & $28.32 \pm 1.37^{\mathrm{a}}$ & $28.11 \pm 0.78^{\mathrm{a}}$ & $32.43 \pm 2.19^{\mathrm{a}}$ & $29.26 \pm 0.83^{\mathrm{a}}$ \\
\hline FCR (\%) & $1.83 \pm 0.02^{\mathrm{a}}$ & $1.75 \pm 0.07^{\mathrm{a}}$ & $1.44 \pm 0.03^{\mathrm{b}}$ & $1.40 \pm 0.05^{\mathrm{b}}$ \\
\hline FCE (\%) & $54.73 \pm 0.49^{\mathrm{b}}$ & $57.23 \pm 2.2^{\mathrm{b}}$ & $69.54 \pm 1.5^{\mathrm{a}}$ & $71.71 \pm 4.28^{\mathrm{a}}$ \\
\hline PER (\%) & $1.36 \pm 0.01^{\mathrm{b}}$ & $1.42 \pm 0.05^{\mathrm{b}}$ & $1.72 \pm 0.04^{\mathrm{a}}$ & $1.76 \pm 0.1^{\mathrm{a}}$ \\
\hline PI (\%) & $0.28 \pm 0.01^{\mathrm{a}}$ & $0.28 \pm 0.01^{\mathrm{a}}$ & $0.32 \pm 0.02^{\mathrm{a}}$ & $0.29 \pm 0.01^{\mathrm{a}}$ \\
\hline
\end{tabular}

Means in the same row with similar super scripts are not significantly different $(\mathrm{P}>0.05)$.

Results of proximate composition of the fish at the inception and conclusion of the experiment were as indicated in Table 6. The crude protein content of the fish at the end across all treatments was higher than at the start. All vales were significantly different except between D0 and D15 with a peak at D20 and minimum at D15. The highest lipid content in D25 did not differ significantly from D20 but from D0 and D15 which both were similar. Ash content of the fish were significantly the same across all experimental sets with random trend. NFE of the fish carcass had its highest significant value in D15 and lest in D20 without any defined trend among the treatments. The statuses of other components are shown in the table.

Table 6 Proximate composition of 0 . niloticus fed different levels of dietary D. regia seed meal for 16 weeks

\begin{tabular}{|l|l|c|c|c|c|}
\hline \multirow{2}{*}{ Component } & Initial \% body composition & \multicolumn{4}{|c|}{ Final \% body composition } \\
\cline { 2 - 6 } & & D0 & D15 & D20 & D25 \\
\hline Moisture & $6.246 \pm 0.003$ & $68.81 \pm 0.06^{\mathrm{a}}$ & $67.97 \pm 0.06^{\mathrm{c}}$ & $68.34 \pm 0.17^{\mathrm{b}}$ & $68.59 \pm 0.12^{\mathrm{ab}}$ \\
\hline Crude protein & $42.82 \pm 0.202$ & $59.85 \pm 0.18^{\mathrm{c}}$ & $59.32 \pm 0.17^{\mathrm{c}}$ & $62,27 \pm 0.26^{\mathrm{a}}$ & $60.55 \pm 0.23^{\mathrm{b}}$ \\
\hline Lipid & $16.82 \pm 0.012$ & $5.63 \pm 0.11^{\mathrm{b}}$ & $5.14 \pm 0.29^{\mathrm{b}}$ & $7.39 \pm 0.06^{\mathrm{a}}$ & $8.03 \pm 0.35^{\mathrm{a}}$ \\
\hline Ash & $22.14 \pm 0.002$ & $17.32 \pm 0.19^{\mathrm{a}}$ & $16.96 \pm 0.22^{\mathrm{a}}$ & $17.4 \pm 0.15^{\mathrm{a}}$ & $16.8 \pm 0.3^{\mathrm{a}}$ \\
\hline Fibre & $15.76 \pm 0.001$ & $12.41 \pm 0.29^{\mathrm{a}}$ & $11.55 \pm 0.29^{\mathrm{b}}$ & $11.48 \pm 0.18^{\mathrm{b}}$ & $11.28 \pm 0.09^{\mathrm{b}}$ \\
\hline NFE & $2.57 \pm 0.005$ & $4.88 \pm 0.06^{\mathrm{b}}$ & $6.86 \pm 0.07^{\mathrm{a}}$ & $1.75 \pm 0.58^{\mathrm{d}}$ & $3.2 \pm 0.23^{\mathrm{c}}$ \\
\hline Kilo calories & $332.55 \pm 0.010$ & $322.9 \pm 0.22^{\mathrm{c}}$ & $332.06 \pm 0.06^{\mathrm{a}}$ & $327.83 \pm 0.23^{\mathrm{b}}$ & $328.31 \pm 0.17^{\mathrm{b}}$ \\
\hline
\end{tabular}

Means in the same row with similar super scripts are not significantly different $(\mathrm{P}>0.05)$.

Table 7 Mean Haematological parameters of 0 . niloticus fed experimental diets

\begin{tabular}{|c|c|c|c|c|c|}
\hline \multirow[t]{2}{*}{ Parameters } & \multicolumn{4}{|c|}{ Treatment } & \multirow[t]{2}{*}{ Reference interval } \\
\hline & DO & D15 & D20 & D25 & \\
\hline WBC $\left(10^{9} / \mathrm{l}\right)$ & $3.47 \pm 333^{\mathrm{a}}$ & $2.7 \pm 666^{b}$ & $0.43 \pm 115^{\mathrm{d}}$ & $1.86 \pm 577^{c}$ & NA \\
\hline $\operatorname{RBC}\left(10^{12} / 1\right)$ & $1.51 \pm 5.77^{\mathrm{ab}}$ & $1.54 \pm 1.27^{\mathrm{ab}}$ & $1.41 \pm 1.15^{b}$ & $1.74 \pm 5.77^{\mathrm{a}}$ & $1.91-2.83$ \\
\hline $\mathrm{Hb}(\mathrm{g} / \mathrm{dl})$ & $7.2 \pm 0.6^{\mathrm{d}}$ & $7.5 \pm 0.12^{\mathrm{b}}$ & $7.3 \pm 0.12^{\mathrm{c}}$ & $8.8 \pm 0.06^{\mathrm{a}}$ & $7.0-9.8$ \\
\hline Hct $(\%)$ & $22 \pm 0.07^{\mathrm{a}}$ & $23 \pm 0.12^{\mathrm{a}}$ & $22 \pm 0.11^{\mathrm{a}}$ & $27 \pm 0.06^{\mathrm{a}}$ & $22-37$ \\
\hline $\operatorname{MCV}(\mathrm{fl})$ & $142 \pm 0.06^{c}$ & $153.07 \pm 0.24^{\mathrm{b}}$ & $155.43 \pm 0.07^{\mathrm{a}}$ & $152.7 \pm 0.06^{b}$ & $115-183$ \\
\hline $\mathrm{MCH}(\mathrm{pg})$ & $47.70 \pm 0.06^{\mathrm{d}}$ & $51.00 \pm 0.12^{\mathrm{b}}$ & $51.73 \pm 0.13^{\mathrm{a}}$ & $50.60 \pm 0.06^{c}$ & $28.3-42.3$ \\
\hline $\mathrm{MCHC}$ g/dl) & $33.600 \pm 0.06^{\mathrm{a}}$ & $33.300 \pm 0.12^{\mathrm{b}}$ & $33.307 \pm 0.13^{b}$ & $33.100 \pm 0.06^{c}$ & $22-29$ \\
\hline
\end{tabular}


Table 7 highlights the mean haematological indices of the fish at the end of the feeding trial all of which marked certain degrees of significant difference $(P<0.5)$ among the treatments except the hematocrit values.

Degutted and dressed weights were non-significant with minimum values in fish fed D15 and maximum values in fish fed D2 0 respectively (Table 8). The lowest fillet weight in D15 and highest in D20 were however significant $(P<0.05)$. The magnitude of visceral weight recorded across the different treatment was marginal and insignificant. Generally, the mean percentage composition of discarded parts in the carcasses of the red tilapia exhibited no significant difference $(P$ $>0.05$ ) among fish on the various treatments though minor random variations occurred within the range between the highest (D25) and the lowest (D20).

Table 8 Fillet yield of $O$. niloticus fed different levels of dietary D. regia seed meal for 16 weeks

\begin{tabular}{|l|l|l|l|c|}
\hline Parameters & D0 & D15 & D20 & D25 \\
\hline whole weight (g) & $50.89 \pm 3.83^{\mathrm{b}}$ & $52.2 \pm 5.69^{\mathrm{ab}}$ & $68 \pm 4.13^{\mathrm{a}}$ & $62.85 \pm 4.95^{\mathrm{ab}}$ \\
\hline whole length (cm) & $17.94 \pm 0.46^{\mathrm{a}}$ & $17.66 \pm 0.69^{\mathrm{a}}$ & $19.44 \pm 0.48^{\mathrm{a}}$ & $17.89 \pm 0.49^{\mathrm{a}}$ \\
\hline weight of scaled fish(\%) & $.68 \pm 1.32^{\mathrm{b}}$ & $95.76 \pm 0.09^{\mathrm{a}}$ & $96.71 \pm 0.56^{\mathrm{a}}$ & $97.08 \pm 0.08^{\mathrm{a}}$ \\
\hline weight of scales (\%) & $6.52 \pm 1.58^{\mathrm{a}}$ & $3.86 \pm 0.33^{\mathrm{ab}}$ & $3.25 \pm 0.56^{\mathrm{b}}$ & $2.9 \pm 0.08^{\mathrm{b}}$ \\
\hline weight of fins (\%) & $5.87 \pm 0.49^{\mathrm{b}}$ & $6.24 \pm 0.10^{\mathrm{b}}$ & $6.31 \pm 0.23^{\mathrm{b}}$ & $7.6 \pm 0.31^{\mathrm{a}}$ \\
\hline weight of viscera (\%) & $5.0 \pm 0.51^{\mathrm{a}}$ & $5.61 \pm 0.24^{\mathrm{a}}$ & $5.11 \pm 0.20^{\mathrm{a}}$ & $5.49 \pm 0.25^{\mathrm{a}}$ \\
\hline weight of degutted fish (\%) & $77.98 \pm 1.7^{\mathrm{a}}$ & $77.89 \pm 0.82^{\mathrm{a}}$ & $81.46 \pm 0.97^{\mathrm{a}}$ & $76.14 \pm 5.02^{\mathrm{a}}$ \\
\hline Head weight (\%) & $33.11 \pm 0.82^{\mathrm{a}}$ & $33.97 \pm 0.10^{\mathrm{a}}$ & $34.09 \pm 0.76^{\mathrm{a}}$ & $34.17 \pm 0.11^{\mathrm{a}}$ \\
\hline weight of dressed fish (\%) & $44.28 \pm 2.01^{\mathrm{a}}$ & $43.26 \pm 1.47^{\mathrm{a}}$ & $47.63 \pm 1.72^{\mathrm{a}}$ & $46.46 \pm 0.84^{\mathrm{a}}$ \\
\hline weight of bones (\%) & $9.03 \pm 0.64^{\mathrm{a}}$ & $8.68 \pm 0.62^{\mathrm{a}}$ & $8.81 \pm 0.29^{\mathrm{a}}$ & $10.2 \pm 0.55^{\mathrm{a}}$ \\
\hline Fillet yield / muscle weight (\%) & $33.16 \pm 1.39^{\mathrm{bc}}$ & $32.76 \pm 0.67^{\mathrm{c}}$ & $36.29 \pm 0.25^{\mathrm{a}}$ & $35.83 \pm 0.85^{\mathrm{ab}}$ \\
\hline weight of discarded parts (\%) & $59.06 \pm 1.02^{\mathrm{a}}$ & $58.22 \pm 0.93^{\mathrm{a}}$ & $57.89 \pm 0.29^{\mathrm{a}}$ & $59.39 \pm 0.99^{\mathrm{a}}$ \\
\hline
\end{tabular}

\section{Discussion}

The ingredients for the formulation of the four feeds were conventional except the Delonix regia seed meals which were used to replace wheat offal at $0.00 \%$ in diet D0, 60\% in D15, 80\% in D20 and $100 \%$ in D25. The proximate compositions of the different feeds were all satisfactory in meeting the nutritional requirements of the fish size used in this work The high survival rate of fish was suggestive of a favourable environmental condition and safety in the consumption of the test feeds over the duration of this experiment. This implies that adequate treatment of D. regia seed could make it suitable for use as feed ingredients for fish and livestock $[15,17,18]$. The levels of all the plant bioactives assayed in the D. regia were low except the oxalate level. This overage might be of little or no consequence to the red tilapia given that the effect of plant anti - nutrients are somewhat dependent on the source, overall concentration and other nutrient compositions of the diet $[8,22,44,45]$. The feeding habit of the fish may also moderate the consequence of anti-nutrient consumed. Members of the Oreochromis genus are associated with plastic throphic mode based on their environment and other composite species [46] thriving on diets consisting of phytoplankton, periphyton, aquatic macrophytes, benthic fauna and detritus [47]. Certain adaptive capacities might have been acquired for them to manage some levels of anti-nutrients safely in diverse plant diets. Umaru et al [48] and Habtamu and Negussie [22] noted that insoluble calcium oxalate in the gut can be vitiated in faeces or by gastrointestinal flora such as Oxalobacter formigenes. The mortality recorded during the experiment appeared non-related to the feed quality following its random distribution among feeds rather, it could have resulted from stocking and measurement stress. Similar observations were made by [49] on Ictalurus furcatatus fed diet with soybean replacing fish meal at various levels up to 100\%, and [50] on Oreochromis niloticus fed varying levels of Chaya leaf meal.

The proximate compositions of the experimental feed revealed a very close range of crude protein, increasing values of crude fibre corresponding to increasing inclusion levels of wheat offal, and ascending levels of lipid with rising levels of DSM which incidentally had high lipid content especially after processing. The increase in lipid content after the treatments possibly follows the report of [21] that fermentation caused increased levels of lipids probably by enhanced 
activities of lipolyptic enzymes generating more free fatty acids. The relative higher values of crude fibre in diets D0 and D15 has the implication of limited utility as an energy source [51]. Conversely, the relative higher levels of lipid in diets D20 and D25 implied dietary energy supplementation and favourable energy to protein ratio that might have promoted efficient crude protein utilization for better growth of fish on these treatments. The higher estimates of PER in these feeds are further evidences of better dietary protein utilization. According to Abdel-Tawwab [52], PER indicates protein quality, quantity and amino acids balance. Therefore, the highest significant value of PER in fish fed the highest levels of DSM diets in this study might indicate better protein quality. Bake [18] recorded the highest weight gain in fish fed 10\% DSM which also had the best specific growth rate while fish fed 20 and 30\% dietary DSM showed progressive decline in these indices from $10 \%$ to $30 \%$. These differences might be accounted for by the difference in the nutrient sources and proximate composition of feeds, and differential sizes of fish used in the two experiments. In this experiment, nutritional differences between wheat offal and DSM could specify differences in the overall dietary protein quality that might have influenced growth. Results obtained by authors working on different growth stages of tilapia have shown that nutrient and energy requirements at different growth stages vary to some extent [53 - 58]. Similarly, the specific growth rate recorded in this experiment is lower than [18] as the initial weight of the fish used here $(12.37 \pm 0.76 \mathrm{~g})$ was higher than 1.17-1.21g in [18]. The initial weight here was however similar to $10.72 \pm 2.5 \mathrm{~g}$ used by [36] for red tilapia. The daily growth rate and growth trend recorded in this experiment also agreed with [36] who obtained $0.4-1.37 \mathrm{gday}^{-1}$. This supports the fact that the growth performance of fish is a function of size and age besides the culture environment [59 -62]. The growth trend in this experiment showed the highest weight gain within the first six weeks of stocking similar to the report of [36]. This probably might relate to the onset of reproductive activities following [36] report that fry were obtained from Nile tilapia and red tilapia 2 and 3 months respectively after stocking. The highest level of feed consumption in the fish fed higher levels of DSM on one hand appears to be a function of the fish size, and on the other hand implied that fermentation, cooking and drying of the D. regia seeds greatly reduced the anti- nutrients present particularly, tannin which is implicated in unpalatability [21], to enhance the taste and utilization of the feed especially, with the incorporation of lysine and methionine $[45,51]$.

Blood is believed to be the most appropriate indicator of the general condition of the animal [63] through which examination of both the physiological and pathological alternations in fishes can be effectively and precisely detected $[64,65]$. According to Fagbenro et al. [66], this analysis could assist to ascertain the implications of the diets and other stressing factors on fish health. The value of the blood parameters obtained in this work were sufficiently high and stable among the various treatments indicating the overall safety of the fish on consuming the experimental feeds. The leucocytes and the thrombocytes are known to be the principal components of the organic defense system of the body [67]. The recorded value of WBC was higher than [63] $108.67 \times 10^{3} \mathrm{ml}^{-1}-238 \times 10^{3} \mathrm{ml}^{-1}$ on Nile Tilapia but lower than [67] $1.95 \times 10^{6} \mu \mathrm{l}^{-1}$ for uninfected and $2.95 \times 10^{6} \mu \mathrm{L}^{-1}$ for Flavobacterium columnare infected tilapia, and [68] on Nile Tilapia. This implies that the red tilapia on the varying inclusion levels of dietary flamboyant seed meal feeding trial had achieved some measures of good health. According to Akinwade et al. [69], remarkable increase in WBC count of a fish and animals is a function of immunity and animals' resistance to the diseases. Das [70] asserted that increased leucocyte count was a protective response to stress in wild Clarias gariepinus. Low leucocyte count would therefore imply compromised immunity and high vulnerability to ailment. Stress in this experiment could mostly be attributed to fluctuation in water temperature $\left(24-31^{\circ} \mathrm{C}\right)$, and perhaps, bi-weekly growth data collection. dos Santos [71] reported the best temperature for the optimal growth performance of red tilapia (Oreochromis niloticus) to be $28{ }^{\circ} \mathrm{C}$. Red blood cells (RBC), the erythrocyte constant (MCV, MCH and MCHC) and the Sanguine constant (haemoglobin and PCV) were all within the range obtained for Nile tilapia by [72] and [63] but to some extent non-consistent with [73] with respect to RBC, MCH and MCHC. The efficiency of oxygen transport between the respiratory system and the tissues is dependent to a large extent on erythrocyte characteristics [74]. Similarly, MCH, MCV and MCHC establish relationship on the size, form and haemoglobin content of red blood cells and allow the evaluation of morphological and chronic types of some anaemia sometimes, indicating the aetiological diagnosis, evolution and efficiency of attendance [75]. The variation in some haematological parameters recorded in this work might follow the remark by [76] that the reference values established for haematological parameters and biochemical tests might not be a holistic representation of those of a specified population or animal species thereby necessitating caution on the interpretation of a wide range of physiological variations observed. This is consequent on the fact that haematological indices vary based on such factors as the fish species, age, cycle of sexual maturity, health condition [77], sex, breeding system, feeding, lineage and environmental condition [76] as well as errors and absence of analytical standards [65]. The variation in the haematological profile of the red tilapia in this experiment lack definite trends among treatment hence, could relate more to the level of gonadal activity of individual fish and sex ratios which were rather random among the treatments, than feed type.

Fish fillet is fish flesh without viscera, bone and the head [78]. The fillet may be with or without the skin on [79]. Most of the productions are available to market as fresh products. However, the consumption of processed and frozen foods has the convenience of foods taking less time in preparation [80]. Filleting reduces bulk in transportation of fresh fish 
product along the marketing chain, enhances cooking efficiencies of house wives and chefs [81 - 83]. According to Adeyemo [83], filleting of tilapia is well practiced in Tanzania and mainly for export. In Nigeria however, fish filleting is really not common and may be restricted to products in the supermarkets as against the high popularity in the developed world. Fillets production can create new windows of opportunity for investment and greater returns on tilapia culture arising from enhanced consumption of decent products from otherwise small sized fish with many sharp bones. FAO [84] stated that a large proportion of cultural tilapia is marketed as fillets and according to [85] and [86], fillet and carcass yields are very vital indices for both fish processing industry and fish farmers because they can determine the economic worth of a fish as well as add value to the ultimate product. The range of fillet yield obtained in this work with a minimum at D0 and a significant maximum at D20 was similar to 30-37 \% in [84] and [87] on Nile tilapia as well as 31.3\% and 33.4\% in [88] and [89] respectively on red tilapia. The fish on D20 and D25 diets with the highest total weight also produced the highest percentage fillet weight which corresponded with better protein utilization in elaboration of muscle mass as evident in the PER and PI values. This tends to agree with the observations of [90] and [91] on Oreochromis niloticus, that direct relationship exists between the fish total weight and its fillets yield. Garcia et al. [92] opined that growth trait, fillet yield and quality traits are of great importance in livestock breeding. Nutritional intervention that could promote rapid growth for the attainment of large sized fish with significant fillet yield ultimately actualizes the breeding goal.

\section{Conclusion}

The red strain of Oreochromis niloticus is fast growing and its unique colouration makes it even more attractive as a food and ornamental fish. These qualities present favourable economic possibilities to the farmers. The red tilapia had been able to accept the Delonix regia seed based feeds and utilize them for growth. The high survival rates and favourable blood profile of the red tilapia fed the experimental feeds demonstrated that when the flamboyant seeds are properly prepared as in this experiment, they could be safe as fish feed ingredient. Based on the crude protein content of the precise flamboyant variety obtained at a given geographic location, it could be used either as a protein source or basal feed in fish feed formulation. The incorporation of flamboyant seeds into fish feed would greatly help to reduce the cost of feeding fish. 20\% inclusion level of dietary DSM enhanced the highest weight gain, survival and fillet weight of the red tilapia, Oreochromis niloticus in this experiment and is recommended.

\section{Compliance with ethical standards}

\section{Acknowledgments}

I sincerely appreciate the assistance of Miss Victoria William Sunday in the course of executing this research work.

\section{Disclosure of conflict of interest}

All the authors hereby disclose no conflict of interest/competing interest.

\section{Statement of ethical approval}

This research is in full compliance with ethical standard in the handling of the animal specimen (fish) used for this study.

\section{References}

[1] Jamu DM, Ayinla AO. Potential for the development of aquaculture in Africa. NAGA. 2003; 26(3): 9-13.

[2] Marimuthu K, Umar R, Muralikrishnan S, Xavier R, Kathiresan S. Effect of different feeding application rate on growth and survival and cannibalism of African catfish, Clarias gariepinus fingerlings. Emirate Journal of Food and Agriculture. 2011; 23(4): 330-337.

[3] Ahmed I, Maqbool A. Effects of dietary protein levels on the growth, feed utilization and haemato-biochemical parameters of freshwater fish, Cyprinus Carpio Var. Specularis. Fisheries and Aquaculture Journal. 2016 ; 8: 187.

[4] Madu CT, Akilo KT. The use of live maggot and live tilapia fry as unconventional diets for juveniles of the catfish. In: Eyo AA, ed. Fish nutrition and Fish Technology. 2001; 72-75.

[5] Balogun JK, Abdullahi AS, Auta J, Ogunlade DP. Feed conversion, protein efficiency, digestibility and growth performance of Oreochromis niloticus fed Delonix regia seed meal. Proceeding of the National Conference of Fisheries Society of Nigeria. 2004; 23-29. 
[6] Fagbenro OA, Akande TT, Fapound 00. Use of roselle (Hibiscus Sabdariffa) seed meal as a soybean meal replacer in practical diets for fingerlings of African catfish (Clarias gariepinus), Proceeding of the Third International Conference on African Fish and Fisheries, Cotonou, Benin. 10-14 November 2003.

[7] Gabriel UU, Akinrotimi OA, Bekibele DO, Onunkwo DN, Anyanwu PE. Locally produced fish feed: Potentials for aquaculture development in Sub-Saharan Africa. African Journal of Agricultural Research. 2007; 2(7): $287-295$.

[8] Azaza MS, Mensi F, Kammoun W, Abdelouaheb A, Brini B, Kraïem MM. Nutritional evaluation of waste date fruit as partial substitute for soybean meal in practical diets of juvenile Nile tilapia, Oreochromis niloticus L. Aquaculture Nutrition. 2009; 15: 262-272.

[9] Mandal S, Ghosh K. Accumulation of tannin in different tissues of Indian Major carps and exotic carps. Aquaculture Research. 2010; 41: 945-948.

[10] Mandal S, Ghosh K. Inhibitory effect of Pistia tannin on digestive enzymes of Indian major carps: an in vitro study. Fish Physiology and Biochemistry. 2010; 36: 1171-1180.

[11] Abowei JFN, Ekubo AT. A review of conventional and unconventional feed in fish nutrition. Department of Biological Sciences, Faculty of Science, Niger Delta University, Wilberforce Island, Bayelsa State, Nigeria. 2011; 20-27.

[12] Tulli F, Chini Zittelli G, Giorgi G, Poli BM, Tibaldi E, Tredici M. Effect of the inclusion of dried Tetraselmis suecica on growth, feed utilization, and fillet composition of European sea bass juveniles fed organic diets. Journal of Aquatic Food Production and Technology. 2012; 21: 188-197.

[13] Egwui PC, Mgbenka BO, Ezeonyejiaku CT. Moringa plant and its use as feed in aquaculture development. Animal Research International. 2013; 10(1): 1673-1680.

[14] Odulate DO, Idowu AA, Fabusoro AA, Odebiyi CO. Growth performance of Juvenile Clarias gariepinus (Burchell, 1822) fed Ipomea aquatica based diets. Journal of Fisheries and Aquatic Science. 2004; 9(6): 468-472.

[15] Bake GG, Yusuf I, Sadieu, SOE. Evaluation and nutrient quantity of toasted flamboyant seed (Deronix regia) meal in the diet of Clarias gariepinus fingerlings. Journal of Agriculture and Economic Research International. 2016; 5(2): $1-9$.

[16] Umanah SI, George EM, David GS. Growth performance and feed utilization of Heterobranchus bidorsalis fed with flamboyant seed meal substituted for wheat offal. Asian Journal of Biological Science. 2019; 12(4): 842-850.

[17] Alemede IC, Adama JY, Ogunbajo SA, Abdulahi J. Haematological parameters of savanna brown does fed varying dietary levels of flamboyant tree seed meal. Pakistan Journal of Nutrition. 2010; 9(2): 167-170.

[18] Bake GG, Martins EI, Sadiku SOE. Nutritional evaluation of varying levels of cooked flamboyant seed meal (Delonix regia) on the growth performance and body composition of Nile Tilapia (Oreochromis niloticus) fingerlings agriculture. Forestry and Fisheries. 2014; 3(4): 233-239.

[19] Grant G, Moore, IJ, Mckenzie NH, Doward PM, Stewart JC, Teleck L, Psuztai A. A Survey of haemaglutination properties of several tropical seeds. Livestock Research for Rural Development. 1991; 3: 1-7.

[20] Sogbesan OA. Effect of different organic substrates on growth and survival long winged termite (Macromeres subhyarius) under laboratory conditions. African Journal of General Agriculture. 2006; 2(2): 37-44.

[21] Soetan, KO, Oyewole, OE. The need for adequate processing to reduce the antinutritional Factors in plants usedas human foods and animal feeds: A review. African Journal of Food Science. 2009; 3(9): 223-232.

[22] Habtamu FG, Negussie R. Anti-dietary factors in plant foods: Potential health benefits and adverse effects. International Journal of Nutrition and Food Sciences. 2014; 3(4): 284-289.

[23] Soetan KO. Pharmacological and other beneficial effects of anti-nutritional Factors in plan - A Review. African Journal of Biotechnology. 2008; 7(25): 4713-4721.

[24] Haruna SS, Ahmed O, Titilayo JO. Nutritional and anti-nutritional composition of Lantana camara leaf. Journal of Investigation in Biochemistry. 2015; 4: 58-60.

[25] Galman OR, Avtalion RR. A preliminary investigation of the characteristics of red tilapias from the Philippines and Taiwan. In: International Symposium on Tilapia in Aquaculture, Fishelson L, Yaron Z, eds. Tel Aviv, Israel: Tel Aviv University Publisher. 1983; 291-301. 
[26] Lovshin LL. Criteria for selecting Nile tilapia and red tilapia for culture. In: Tilapia Aquaculture in the 21st century, Proceedings of the Fifth International Symposium on Tilapia Aquaculture. Fitzsimmons K, Filho JC, eds. Rio deJanerio. 2000.

[27] Behrends LL, Nelson RG, Smitherman RO, Stone NM. Breeding and culture of red-gold color phase of tilapia". Journal of World Mariculture Society. 1982; 13: 210-220.

[28] Hulata G, Karplus I, Harpaz S. Evaluation of some red tilapia strains for aquaculture: Growth and color segregation in hybrid progeny. Aquaculture Research. 1995; 26: 765-771.

[29] Kuo CM. The development of tilapia culture in Taiwan. ICLARM Newsletter. 1984; 7: 12-14.

[30] Olopade OA, Taiwo IO, Lamidi AA, Awonaike OA. Proximate composition of Nile tilapia (Oreochromis niloticus) (Linnaeus, 1758) and tilapia hybrid (red tilapia) from Oyan Lake, Nigeria. Bulletin of University of Agricultural Sciences and Veterinary Medicine Food Science and Technology. 2016; 73(1): 19-23.

[31] Moharram SG, Raky FA. Effect of varying dietary protein sources on growth and spawning performance and gonad maturation of red tilapia reard in sea water. Pakistan Journal of Biological Sciences. 2007; 10: 3742-3751.

[32] Templonuevo RMC, Cruz EMV. Responses of red Nile tilapia (Oreochromis niloticus L) subjected to social and confinement stress. CLSU International Journal of Science and Technology. 2016; 1(2): 7-14.

[33] Thodesen J, Rye M, Wang YX, Li SJ, Bentsen HB, Gjedrem T. Genetic improvement of tilapias in China: Genetic parameters and selection responses in growth, pond survival and cold-water tolerance of blue tilapia (Oreochromis aureus) after four generations of multi-trait selection. Aquaculture. 2013; 396-399: 32-42.

[34] Association of Official Analytical Chemist (AOAC). Official methods of Analysis of AOAC 12th edition, Washington DC: AOAC. 2005; 17: 32-36.

[35] Latta M, Eskin M. Simple colorimetric method of phytate determination. Journal of Agriculture and Food Chemistry. 1980; 28: 1313-1315.

[36] Kohinoor AHM, Modak PC, Hussain MG. Growth and production performance of red tilapia and Nile tilapia (Oreochromis niloticus Lin.) under low-input culture system. Bangladesh Journal of Fisheries Research. 199; 3(1): 11-17.

[37] Bucur C, Costache M, Oprea D, Marica N. Studies and Observations on the Spawning of Oreochromis niloticus Species Reared at SCDP Nucet-Dambovita. Scientific Papers Animal Science and Biotechnologies. 2012; 45(2): 16.

[38] Mirea (Ciortan) C, Cristea V, Grecu RI, Dediu L, Adina S. Results regarding growth performance of Nile tilapia (Oreochromis niloticus, Linnaeus, 1758) fed with an additive feed, Vitamin C, in a recirculating aquaculture system. Scientific Papers Animal Science and Biotechnologies. 2013; 46(2): 238-243.

[39] Blaxhall PC, Daisley KW. Routine haematological methods for use with fish blood. Journal Fish Biology. 1973; 5: 771-781.

[40] Dacie JV, Lewis SM. Practical Haematology. London: Churchill Livingstone. 1991.

[41] Hepher B. Nutrition of pond fishes. UK: Cambridge University Press. 1988.

[42] Wilson RP. Amino acid and protein requirement of fish. In: Cowey CB, Mackie AM, Bell JG, eds. Nutrition and feeding in fish. London: Academic press. 1989; 1-16.

[43] TBoujard L, Labbe L, Auperin B. Feeding behaviour, energy expenditure and growth of Rainbow trout in relation to stocking density and food accessibility. Aquaculture Research. 2002; 33(15): 1233-1242.

[44] Azaza MS, Mensi F, Ksouri J, Dhraief MN, Brini B, Abdelmouleh A, Kraïem MM. Growth of Nile tilapia (Oreochromis niloticus L.) fed with diets containing graded levels of green algae ulva meal (Ulva rigida) reared in geothermal waters of southern Tunisia. Journal of Applied Ichthyology. 2008; 24: 202-207.

[45] Omnes MH. Le Goasduff J, Le Delliou H, Le Bayon N, Quazuguel P, Robin JH. Effects of dietary tannin on growth, feed utilization and digestibility, And carcass composition in juvenile European seabass (Dicentrarchus labrax L.). Aquaculture Reports. 2017; 6(2017): 21-27.

[46] Bwanika GN, Akanga BM, Kizito Y, Chapman LJ, Baliwa, J. Observation on the biology of Nile tilapia, Oreochromis niloticus L.in two Ugandan crater lakes. African Journal of Ecology. 2004; 42(1): 93-101. 
[47] El-Sayed A-FM. Taxonomy and basic biology. In: El-Sayed A-FM, ed. Tilapia culture (2nd Ed.). London: Academic Press. 2020; 21- 31.

[48] Umaru HA, Adamu R, Dahiru D, Nadro MS. Levels of antinutritional factors in some wild edible fruits of Northern Nigeria. African Journal of Biotechnology. 2007; 6: 1935-1938.

[49] Webster CD, Goodgame T, Tiu LS, Tidwell JH. Total replacement of soybean meal, with various percentages of supplemental L-methiomine, in diets for blue catfish (Ictalurus furcatus). Aquaculture Research. 1995; (26): 299306.

[50] Obasa SO, Femi O, Adeosun FI, Odulate DO. Growth response, nutrient utilization and survival of Nile tilapia (Oreochromis niloticus) fed varying levels of chaya leaf (Cnidoscolus Chayamansa) meal. Asset Series A. 2007; $7(1): 160-166$.

[51] Chatvijitkul S, Davies DA, Lim CE. Lipid extracted distillers dried grains with solubles (LE-DDGS) as a partial replacement for soybean meal in hybrid tilapia (Oreochromis niloticus $\times$ 0. aureus) diets. Aquaculture. 2016; 459: 131-136.

[52] Abdel-Tawwab M, Ahmad MH, Khattab YAE, Shalaby AME. Effect of dietary protein level, initial body weight, and their interaction on the growth, feed utilization, and physiological alterations of Nile tilapia, Oreochromis niloticus. Aquaculture. 2010; 298: 267-274.

[53] De Silva SS, Perera MK. Effects of dietary protein levels on growth, food conversion and protein use in young Tilapia nilotica at four salinities. Transaction of the American Fisheries Society. 1985; 114: 584-589.

[54] Lovell T. Nutrition and feeding of fish. New York: Van Nostrand Reinhold. 1989.

[55] El-Sayed AM, Teshima S. Protein and energy requirements of Nile tilapia Oreochromis niloticus, fry. Aquaculture. 19 ; 103: 55-63.

[56] Al-Hafedh YSA. Effects of dietary protein on growth and body composition of Nile tilapia Oreochromis niloticus. Aquaculture Research. 1999; 30: 358-393.

[57] El-Dahlhar A, Zeweil H, El-Tawil N. Effect of protein and energy levels in commercial diets on growth performance of juvenile Nile Tilapia (Oreochromis niloticus). Egyptian Journal of Aquatic Biology and Fisheries. 2000; 4(2): 267-285.

[58] Mohammadi M, Sarsanji AH, Haghighi TD, Webster C, Rajabipour F, Mashali N, Bitaraf A, Hefeziyah, M. Optimization of dietary protein in all male Nile tilapia (Oreochromis niloticus) reared in inland saline water. Animal Nutrition and Feed Technology. 2014; 14: 91-99.

[59] Verreth JAJ, Eding EH, Rao RM; Huskens F, Segner H. A review of feeding practices, growth and nutritional physiology in larvae of catfishes Clarias gariepinus and Clarias batrachus. Journal of the world Aquaculture Society. 1993; 24: 135-144.

[60] Lee SM, Cho SH, Kim KD. Effects of dietary protein and energy levels on growth and body composition of juvenile flounder Paralichtys olivaceus. Journal of World Aquaculture Society. 2000; 30: 306-315.

[61] Marimuthu K, Cheen AC, Muralikrishnan S, Kumar D. Effect of different feeding frequency on the growth and survival of African catfish (Clarias gariepinus) fingerlings. Advance Environmental Biology. 2010; 4: $187-193$.

[62] Hseu JR, Hwang PP, Ting YY. Morphometric model and laboratory analysis on intracohort cannibalism in giant grouper Epinephelus lanceolatus fry. Fisheries Science. 2004; 70: 482-486.

[63] Kefas M, Abubakar KA, Ja'afaru A. Haematological indices of tilapia (Oreochromis niloticus) from Lake Geriyo, Yola, Adamawa State, Nigeria. International Journal of Fisheries and Aquatic Studies. 2015; 3(1): 9 - 14.

[64] Kori-Siakpere O, Ake JEG, Idoge E. Haematological characteristics of the African snakehead, Parachacnna obscura. African Journal of Biotechnology. 2005; 4(6): 527-530.

[65] Dal'Bó GA, Sampaio FG, Losekann ME, de Queiroz JF, Luiz AJB, Wolf VHG, Gonçalves VT, Carra, ML. Hematological and morphometric blood value of four cultured species of economically important tropical food fish. Neotropical Ichthyology. 2015; 13(2): 439-446.

[66] Fagbenro OA, Adeparusi EO, Jimoh WA. Haematological profile of blood of African catfish (Clarias gariepinus, Burchell 1822) fed sunflower and sesame meal based diets. Journal of Fisheries and Aquatic Science. 2013; 8(1): 80-86. 
[67] Sebastiao FA, Omura N, Sakabe R, Pilarski F. Haematology and productive performance of Nile tilapia (Oreochromis niloticus) naturally infected with Flvobaterium columnare. Brazilian Journal of Microbiology. 2011; 42: 282-289.

[68] El-Saidy DMSD, AS Saad. Effects of partial and complete replacement of soy bean meal with cotton seed meal on growth, feed utilization and haematological indices for mono - sex male Nile tilapia (Oreochromis niloticus) fingerlings. Aquaculture Research. 2011; 42(3): 351-359.

[69] Akinwande AA, Moody FO, Sogbesan OA, Ugwumba AAA, Ovie SO. Haematological response of Heterobranchus longifilis fed varying dietary protein levels. In: Proceeding of the 19th Annual Conference of the Fisheries Society of Nigeria; Ilorin. 2004; 715-18.

[70] Das MK. Studies on the effects of some pesticides and commonly used chemicals on Indian major carp and their ecosystem. [Ph. D Thesis]. Bhubaneswas, India: Orissa University of Agriculture and Technology. 1998.

[71] dos Santos VB, Mareco EA, Silva, MDP. Growth curves of Nile tilapia (Oreochromis niloticus) strains cultivated at different temperatures. Acta Scientiarum. Animal Sciences. 2013; 35(3): 235-242.

[72] Nilza LR, Ligia MM, Dens OS, Rassia BP, Celso VN, Tania UN, Benicio, AF, Benedito PF. Haematological and biochemical values for Nile tilapia (Orechromis niloticus) cultured in semi-intensive system. Acta Scientiarum Biological Sciences. 2003; 25(2): 385-389.

[73] Terry C, Hrubec TC, Stephen AS. Haematology of fish. Veterinary Clinical Pathology. 2000; 174: 1120-1125.

[74] Zhou X, Li M, Abbas K, Wang W. Comparison of haematology and serum biochemistry of cultured and wild Dojo loach Misgurnus anguillicaudatus. Fish Physiology and Biochemistry. 2009; 35: 435-441.

[75] Radu R, Oprea L, Bucur C, Costache M, Oprea D. Characteristics of haematological parameters for carp culture and koi (Cyprinus carpio Linneaus, 1758) reared in an intensive system. Bulletin University of Agricultural Sciences and Veterinary Medicine Animal Science and Biotechnologies. 2009; 66 (1-2): 336-342.

[76] Teixeira MA. Haematological and biochemical profiles of rat (Rattus norvegicu) kept under micro-environmental ventilation system. Brazilian Journal of Veterinary Research and Animal Science. 2000; 37(50).

[77] Blaxhall PC. The haematological assessment of the health of freshwater fish. Journal of Fish Biology. 1972; 4: 593604.

[78] Salisu AAA, Faturoti EO. Effect of different weight classes of processed Clarias gariepinus on yields of fish fillet and fishmeal production. International Journal of Science and Research. 5(4): 1714 - 1717.

[79] Zakes Z, Szczepkowski M, Jankowska B, Kowalska A, Demska-Zakes K. Slaughter yield and growth performance indexes of pikeperch (Sander lucioperca (L.)) selects reared in recirculating aquaculture systems at suboptimal temperatures Archives of Polish Fisheries. 2012; 20: 281-288.

[80] Yasemi M, Motalebi AA, Mohammadzadeh B, Monfared N. Fillet yield, proximate composition and mineral content in Indian spiny halibut psettodes erumei caught from the coastal waters of Buseher (Perusian Gulf). Iranian Journal of Fisheries Science. 2011; 10(3): 519 - 528.

[81] Miller JW. Product quality of cultured fish. FAO Aquaculture Bulletin. 1974; 6(4): 8.

[82] Acharya D. Fillet quality and yield of farmed Atlantic salmon (Salmo salar L.): Variation between families, gender differences, and importance of maturation [Master's thesis]. Oslo, Norway: Department of Animal and Aquacultural Science, Norwegian University of Life Sciences. 2011.

[83] Adeyemo A0. Estimation of fillet yield for four tropical freshwater fish species. Merit Research Journal of Environmental Science and Toxicology. 2013; 1(2): 012-015.

[84] Food and Agriculture Organization (FAO). The state of world fisheries and aquaculture: Opportunities and challenges. Food and Agriculture Organization: Rome, Italy. 2014.

[85] Macedo-Viegas EM, Souza MLR. Pré-processamento e conservação do pescado produzido em piscicultura. In: Cyrino, J.E.P.; Urbinati, E.C.; Fracalossi, D.M.; Castagnolli, N. Tópicos Especiais em Piscicultura de Água Doce Tropical Intensiva. São Paulo: TecArt. 2004; 405-480.

[86] Geraldo AMR, da Cunha L, Hoshiba MA, Cardoso Md' S. da Silva VC, Tamajusuku ASK. Fillet and carcass yield and fillet chemical composition of piava from fish farming and from the wild. Boletim do Instituto de Pesca. 2015; 41(especial): 743 - 749. 
[87] Rutten M, Bovenhuis H, Komen H. Modeling fillet traits based on body measurements in three Nile tilapia strains (Oreochromis niloticus). Aquaculture. 2004; 231: 113-122.

[88] Peterman MA, Phelps RP. Fillet Yields from Four Strains of Nile Tilapia (Oreochromis niloticus) and a Red Variety, Journal of Applied Aquaculture. 2012; 24(4): 342-348.

[89] Garduno-Lugo M, Granados-Alvarez I, Olvera-Novoa M, Munoz-Cordova G. Comparison of growth, fillet yield, and proximate composition between Stirling Nile tilapia (wild type) (Oreochromis niloticus) and red hybrid tilapia (Florida red tilapia x Stirling red O. niloticus) males. Aquaculture Research. 2003; 34(12):1023-1028.

[90] Santos BA, Melo JFB, Lopes PRS, Malgarim MB. Composição química e rendimento do filé da traíra (Hoplias malabaricus). Revista da Faculdade de Zootecnia, Veterinária e Agronomia. 2001; 7-8(1): 140-150.

[91] Souza MLR, Viegas EMM, Sobral PJA, Kronka SN. Efeito do peso de tilápia do Nilo (Oreochromis niloticus) sobre o rendimento e a qualidade de seus filés defumados com e sem pele. Ciência e Tecnologia de Alimentos. 2005; 25(1): 51-59.

[92] Garcia A, Sary C, Karin HM, Ribeiro RE, Lourenco DAL, Tsurata S, Oliveira CA. Fillet yield and quality traits as selection criteria for Nile tilapia (Oreochromis niloticus) breeding. Journal of Animal Science. 2017; 95(4): 103. 